\title{
Simulação de Bloqueios Periféricos Guiados por Ultra-Som: Curva de Aprendizado dos Residentes de Anestesiologia do CET-SMA/HSL *
}

\section{Simulation of Ultrasound-Guided Peripheral Nerve Block: Learning Curve of CET-SMA/HSL Anesthesiology Residents}

\author{
Marilia Bonifácio Baranauskas ${ }^{1}$, Clarita Bandeira Margarido, TSA², Cláudia Panossian ${ }^{1}$, Enis Donizetti Silva, TSA ${ }^{3}$
} Murilo Awada Campanella ${ }^{4}$, Pedro Paulo Kimachi ${ }^{5}$

\section{RESUMO}

Baranauskas MB, Margarido CB, Panossian C, Silva ED, Campanella MA, Kimachi PP — Simulação de Bloqueios Periféricos Guiados por Ultra-Som: Curva de Aprendizado dos Residentes de Anestesiologia do CET-SMA/HSL.

JUSTIFICATIVA E OBJETIVOS: A técnica de ultra-som tem sido cada vez mais utilizada para a realização de bloqueios de nervos periféricos. Existem poucos relatos na literatura que analisam a curva de aprendizado da técnica de ultra-som. O objetivo do estudo foi avaliar a curva de aprendizado dos residentes de Anestesiologia do CET-SMA/HSL em bloqueios periféricos guiados por ultra-som por meio de modelo experimental de gelatina.

MÉTODO: Foi desenvolvido modelo experimental com cuba preenchida de gelatina e azeitona submersa. Nove residentes foram distribuídos aleatoriamente em três grupos (G1, G2 e G3) compostos, cada um, de um R1, um R2 e um R3. Os três grupos receberam explanação teórica. O G1 recebeu duas horas de treinamento prático, o G2 uma hora e o G3 não treinou. Na seqüência, os participantes foram solicitados a posicionar a agulha no ponto médio da parede da azeitona, próximo ao transdutor e reposicionar a agulha entre a azeitona e o fundo da cuba, simulando a injeção perineural do anestésico. Foram avaliadas a velocidade e eficácia das tarefas, além das falhas técnicas.

RESULTADOS: O G1 apresentou média de tempo para realização das tarefas de 37,63 segundos, sem falhas técnicas; no G2

${ }^{*}$ Recebido do (Received from) Instituto de Ensino e Pesquisa (IEP), localizado no Hospital Sírio Libanês (HSL), São Paulo, SP

1. ME do São Paulo Serviços Médicos de Anestesia (SMA) do Hospital Sírio Libanês

2. Doutora em Medicina pela FMUSP, Responsável pela Pesquisa do São PauIo SMA

3. Presidente do São Paulo SMA; Responsável pelo CET do São Paulo SMA

4. $M E_{2}$ do São Paulo SMA do Hospital Sírio Libanês

5. Anestesiologista do São Paulo SMA

Apresentado (Submitted) em 27 de abril de 2007

Aceito (Accepted) para publicação em 30 de dezembro de 2007

Endereço para correspondência (Correspondence to):

Dra. Marilia Bonifácio Baranauskas

Rua Itamarati, 88 - Santa Teresinha

02460-010 São Paulo, SP

E-mail:mariliabaranauskas@ig.com.br

(C) Sociedade Brasileira de Anestesiologia, 2008 observou-se média de 64,40 segundos, ocorrendo duas falhas técnicas e o G3 apresentou média de 93,83 segundos, com 12 falhas técnicas.

CONCLUSÕES: O estudo permite concluir que o maior tempo de treinamento em modelo experimental de bloqueios periféricos guiados por ultra-som melhorou a curva de aprendizado na simulação da técnica.

Unitermos: ANESTESIA, Regional; ENSINO, Simuladores; EQUIPAMENTOS, Ultra-som; TÉCNICAS ANESTÉSICAS, Regional.

\section{SUMMARY}

Baranauskas MB, Margarido CB, Panossian C, Silva ED, Campanella MA, Kimachi PP - Simulation of Ultrasound-Guided Peripheral Nerve Block: Learning Curve of CET-SMA/HSL Anesthesiology Residents.

BACKGROUND AND OBJECTIVES: The use of ultrasound imaging in peripheral nerve block has been increasing. However, there are few reports in the literature on the learning curve of the ultrasound technique. The objective of this report was to evaluate the learning curve of CET-SMA/HSL Anesthesiology residents of ultrasound-guided peripheral block using an experimental agar model.

METHODS: An experimental model was developed by filling a bowl with agar and olives. Nine residents were randomly divided in three groups (G1, G2, and G3), each one with a R1, a R2, and a R3. All three groups received theoretical explanation. G1 also had two hours of practical training, G2 had one hour, and G3 had no training. Residents were then asked to place a needle at the middle of the olive wall, near the transducer, and then reposition the needle between the olive and the bottom of the bowl, simulating the epidural injection of anesthetic. The speed and efficacy of the tasks, as well as technical flaws, were evaluated.

RESULTS: The mean length of time to perform the tasks was 37.63 seconds for G1, without technical flaws; 64.40 seconds for G2, with two technical flaws; and 93.83 seconds for G3, with 12 technical flaws.

CONCLUSIONS: This study allows us to conclude that the longer training of ultrasound-guided peripheral nerve block in an experimental model improved the learning curve of the technique.

Key Words: ANESTHESIA, Regional; ANESTHETIC TECHNIQUES, Regional; EQUIPMENT, Ultrasound; TEACHING, Simulators. 


\section{INTRODUÇÃO}

O ultra-som tem se tornado uma modalidade cada vez mais popular na realização de bloqueios periféricos ${ }^{1}$. As técnicas guiadas por ultra-som baseiam-se na visualização direta dos nervos, da agulha de bloqueios e das estruturas anatômicas adjacentes. Essa visualização das estruturas por meio do ultra-som com transdutores de alta freqüência proporciona ao anestesiologista a segurança do correto posicionamento da agulha e a monitoração da distribuição do anestésico local em tempo real, melhorando, assim, a qualidade do bloqueio. Soma-se a isso a vantagem de evitar complicações neurológicas traumáticas e não-traumáticas (ex.: parestesia, hematoma), diminuição do volume anestésico a ser injetado, quando comparado com as técnicas convencionais, como a estimulação nervosa, procedimentos de perda da resistência ou pesquisa de parestesias ${ }^{2}$. O entendimento clínico e tecnológico das imagens sonográficas da anatomia tem se desenvolvido muito na última década. O uso cotidiano das técnicas guiadas por ultra-som requer um equipamento de alta resolução e um alto grau de treinamento. Anestesiologistas necessitam desenvolver plenamente seus conhecimentos das estruturas anatômicas envolvidas e adquirir uma sólida base em tecnologia de ultra-som, além de habilidades práticas na visualização das estruturas nervosas, pois a adequada realização depende da habilidade do executor.

Há poucos relatos na literatura que analisam a curva de aprendizado com a técnica de ultra-som ${ }^{3}$. O objetivo deste estudo foi avaliar a curva de aprendizado dos residentes de Anestesiologia do CET do São Paulo Serviços Médicos de Anestesia do Hospital Sírio Libanês (SMA/HSL) em bloqueios periféricos guiados por ultra-som por meio de modelo experimental de gelatina ${ }^{4}$.

\section{MÉTODO}

A pesquisa envolveu todos os residentes do CET SMA/HSL. Foram incluídos nove residentes distribuídos aleatoriamente em três grupos, constituídos por um ME1, um ME2 e um ME3 (médicos em especialização do primeiro, segundo e terceiro ano, respectivamente). O primeiro grupo (G1) recebeu orientação teórica sobre o aparelho de ultra-sonografia (USG) e as técnicas de bloqueios. Essa orientação foi ministrada pelo anestesiologista de maior experiência na técnica de bloqueio guiado por USG da equipe. Após explanação teórica, esse grupo realizou duas horas de treinamento livre com a utilização do modelo experimental sob supervisão do mesmo anestesiologista citado. O segundo grupo (G2) recebeu a orientação teórica, porém com apenas uma hora de treinamento livre. O terceiro grupo (G3) recebeu apenas a orientação teórica.

O modelo experimental constituía-se de recipiente com uma azeitona posicionada em seu fundo e recoberta por uma camada de aproximadamente $4 \mathrm{~cm}$ de gelatina escura. Era fundamental que a azeitona não fosse visualizada no interior do recipiente (Figuras 1, 2 e 3 ).

Os residentes foram submetidos às mesmas tarefas. Cada um deles teria três tentativas para realizá-las. As tarefas foram divididas em: 1) visualização correta das estruturas; 2) tocar a azeitona com a ponta da agulha; 3) reposicionar a agulha entre a azeitona e o fundo do recipiente; 4) não tocar o fundo do recipiente com a agulha. Foram consideradas falhas técnicas: não-visualização das estruturas, posicionamento incorreto da agulha, tocar o fundo do recipiente com a agulha. $O$ não-cumprimento de cada uma dessas tarefas, assim como a ocorrência de falhas técnicas, foi avaliado pelo examinador. Todos os residentes foram avaliados pelo

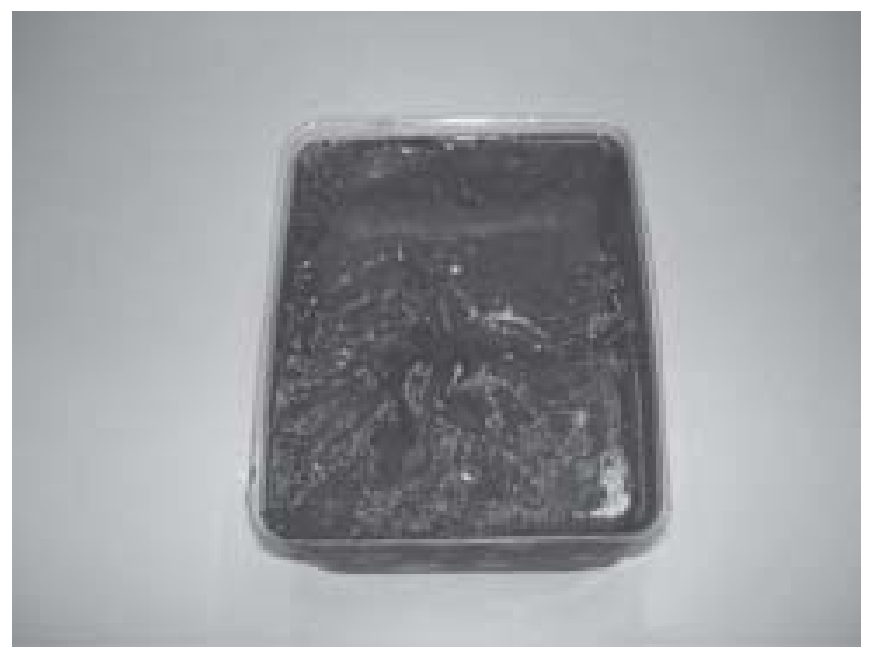

Figura 1 - Modelo Experimental de Gelatina. Sem iluminação direta a azeitona não é visualizada no interior do recipiente com gelatina.

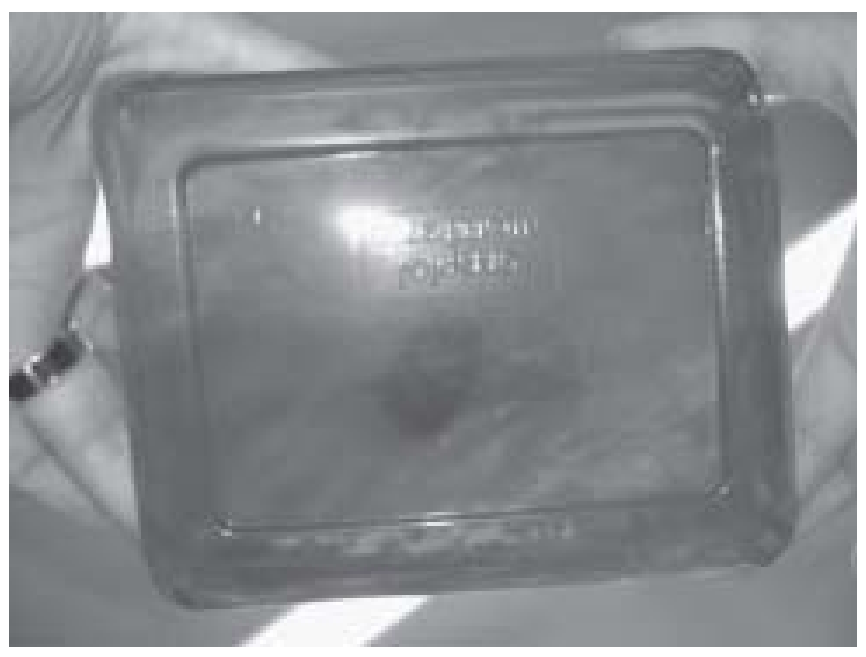

Figura 2 - Modelo Experimental de Gelatina. Com iluminação direta a azeitona é visualizada no interior do recipiente com gelatina. 


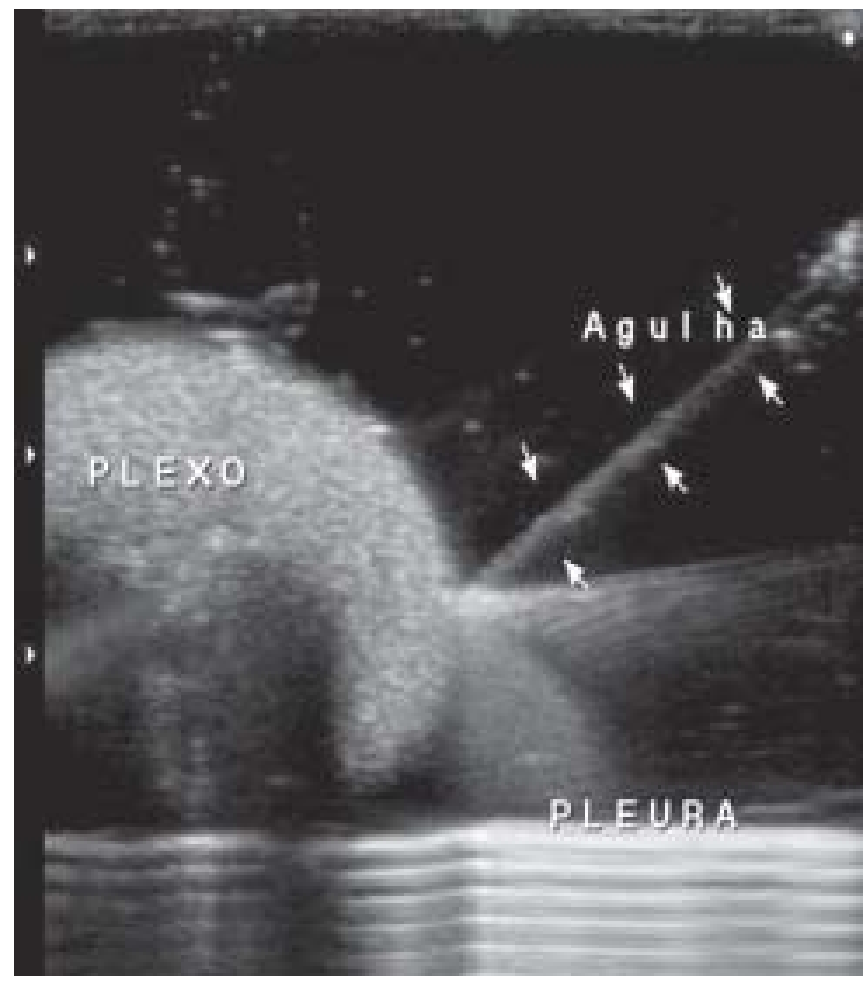

Figura 3 - Imagem Ultra-Sonográfica do Modelo Experimental. O fundo do recipiente do modelo experimental representa a pleura, a azeitona representa o plexo, com a visualização da agulha. mesmo examinador, que desconhecia a qual grupo de prática eles pertenciam.

Foram avaliados o tempo médio para realização das tarefas e o número de falhas técnicas ocorridas em cada grupo.

\section{RESULTADOS}

O G1 apresentou média de tempo para a realização das tarefas de 37,63 segundos, não apresentou falhas técnicas; no G2 observou-se uma média de 64,4 segundos e apresentação de duas falhas técnicas durante as tarefas, e o G3 apresentou média de 93,83 segundos, com 12 falhas técnicas durante a realização das tarefas (Tabela I e Gráfico I).

Tabela I - Distribuição da Ocorrência de Falhas Técnicas nos Grupos

\begin{tabular}{lccc}
\hline & Grupo 1 & Grupo 2 & Grupo 3 \\
\hline $\begin{array}{l}\text { Não-visualização } \\
\text { das estruturas }\end{array}$ & 0 & 0 & 0 \\
$\begin{array}{l}\text { Posicionamento } \\
\text { incorreto da agulha }\end{array}$ & 0 & 2 & 9 \\
$\begin{array}{l}\text { Tocar o fundo do } \\
\text { recipiente }\end{array}$ & 0 & 0 & 2 \\
Total de falhas técnicas & 0 & 2 & 11 \\
\hline
\end{tabular}

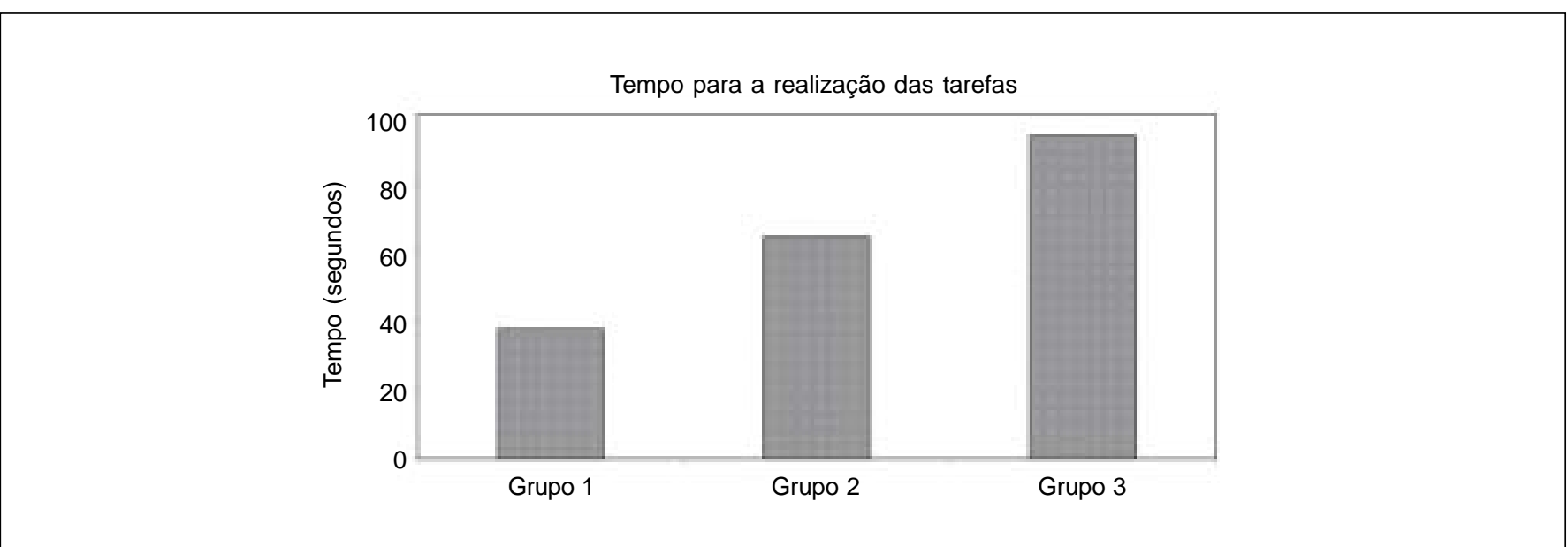

Gráfico I - Tempo Médio para Realização das Tarefas dos Grupos.

\section{DISCUSSÃo}

O uso de simuladores é uma prática comum em ramos de atividade como as indústrias da aviação e nuclear, nas quais operadores devem estar atentos e treinados para lidar com situações que podem trazer conseqüências catastróficas. Treinamento adequado permite respostas rápidas e desenvolvimento de habilidades e aperfeiçoamento da técnica. A
Anestesiologia assemelha-se a esses ramos de atividades, por lidar com situações críticas, que necessitam de respostas imediatas, eficazes e não-iatrogênicas.

A possibilidade de ocorrer complicação quando se realizam bloqueios anestésicos justifica a utilização da assistência ultra-sonográfica, que deve ser desenvolvida previamente à realização de bloqueios nos pacientes, por meio de simulações e treinamentos em modelos experimentais, nas ins- 
tituições de ensino e treinamento, sob supervisão direta e segura de tutores experientes e habilitados.

Nesse estudo, o principal dado encontrado foi a relação entre o maior tempo de treinamento e o melhor desempenho na realização das tarefas, com menor incidência de falhas técnicas, que coincide com os dados encontrados na literatura, reiterando que indivíduos submetidos a treinamentos específicos apresentam melhor desempenho que os nãotreinados ${ }^{5}$.

Os modelos experimentais atualmente utilizados para 0 treinamento das técnicas guiadas por ultra-som consistem em: ombros de porco, peitos de peru, músculo bovino ou peças de gelatina ${ }^{4}$.

O modelo experimental utilizado apresenta várias vantagens, pois é de fácil reprodutibilidade, acessível a qualquer anestesiologista ou CET e de baixo custo. Após o treinamento, os residentes demonstraram maior confiança para realizar os bloqueios guiados por ultra-som em seres humanos. É importante que 0 anestesiologista tenha oportunidade de manusear e se familiarizar com o aparelho de ultra-som previamente à realização da técnica em seres humanos.

Como limitação do estudo, é possível citar o pequeno número de participantes, motivo pelo qual os resultados não receberam análise estatística. Além disso, teria sido ideal a avaliação, antes e após o treinamento, do desempenho dos residentes na realização de bloqueios guiados por ultra-som em seres humanos. Pesquisas complementares são necessárias para validação do modelo de simulação empregado.

O estudo permitiu concluir que o maior tempo de treinamento prático em modelo experimental de bloqueios periféricos guiados por ultra-som melhorou a curva de aprendizado na simulação da técnica.

\section{Simulation of Ultrasound-Guided Peri- pheral Nerve Block: Learning Curve of CET-SMA/HSL Anesthesiology Residents}

\author{
Marilia Bonifácio Baranauskas, M.D.; Clarita Bandeira \\ Margarido, TSA, M.D.; Cláudia Panossian, Enis Donizetti Silva, \\ TSA, M.D.; Murilo Awada Campanella, M.D.; Pedro Paulo \\ Kimachi, M.D.;
}

\section{INTRODUCTION}

Ultrasound imaging is an increasingly popular technique in peripheral nerve block ${ }^{1}$. Ultrasound-guided techniques are based on direct visualization of nerves, needle, and adjacent anatomical structures. This visualization with high-frequency transducers ensures the safety of proper needle placement and real-time monitoring of the distribution of the local anesthetic, therefore improving the quality of the blockade. It also avoids traumatic and non- traumatic (p. ex.: paresthesia, hematoma) neurological complications, and reduction of the volume of anesthetic administered, when compared with conventional techniques, such as nerve stimulation, loss of resistance, or the development of paresthesia ${ }^{2}$.

Clinical and technological understanding of ultrasound images has greatly improved in the last decade. The daily use of ultrasound-guided techniques requires a high-resolution device and a high degree of training. Anesthesiologists should fully develop their knowledge of the anatomical structures involved and acquire a solid background on ultrasound technology, besides the practical ability to visualize nerve structures, since proper performance depends on the ability of the operator.

There are few reports in the literature analyzing the learning curve of the ultrasound technique ${ }^{3}$. The objective of this study was to evaluate the learning curve of Anesthesiology residents of CET of São Paulo Serviços Médicos de Anestesia of the Hospital Sírio e Libanês (SMA/HSL) of ultrasound-guided peripheral blocks using an experimental agar model ${ }^{4}$.

\section{METHODS}

This study involved all CET SMA/HSL residents. Nine residents were randomly divided in three groups, and each group was composed of one R1, one R2, and one R3 (first, second, and third year residents, respectively). The first group (G1) received theoretical orientation on the ultrasound equipment (USG) and blockade techniques. This was done by the more experienced anesthesiologist on USG-guided nerve block. After the theoretical explanation, this group underwent two hours of free training with the experimental model under supervision of the same anesthesiologist. The second group (G2) received theoretical orientation, but only one hour of free training. The third group (G3) received only theoretical orientation. The experimental model consisted of a bowl with an olive at the bottom covered by a 4-cm layer of dark agar. It was paramount that the olive would not be visible (Figures 1, 2, and 3).

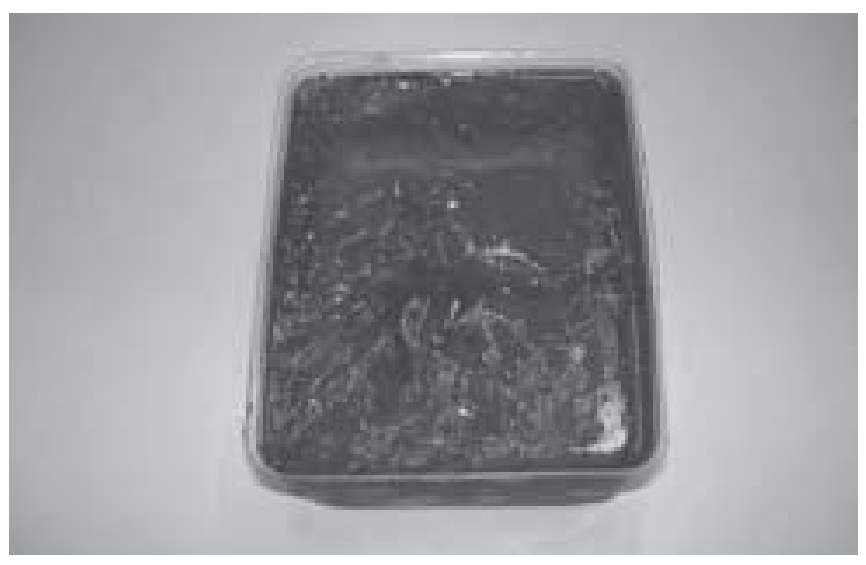

Figure 1 - Experimental Agar Model. The olive inside the bowl with agar cannot be seen without direct illumination. 


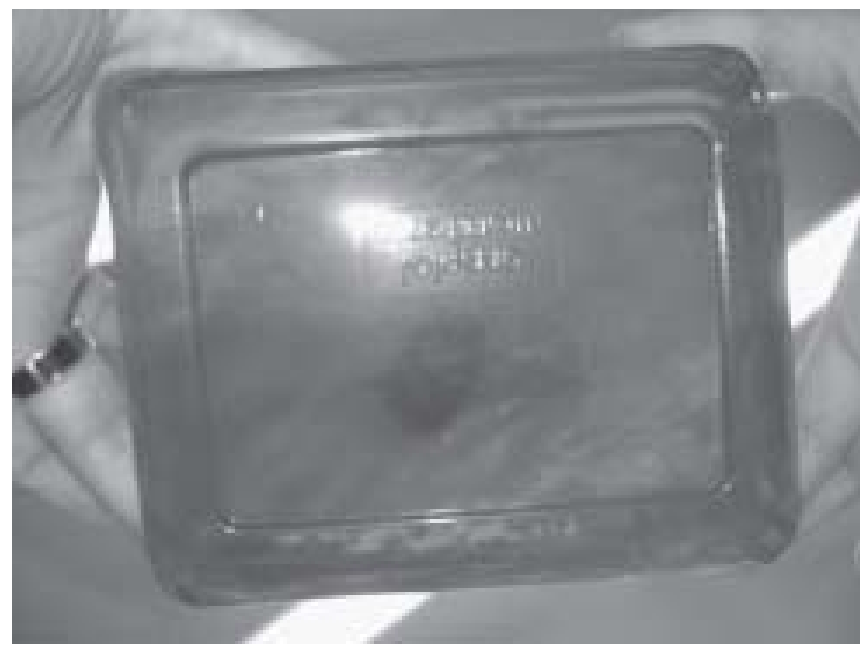

Figure 2 - Experimental Agar Model. Under direct illumination, the olive can be seen inside the bowl with agar.

All residents had to perform the same tasks. Each one was allowed three attempts. Tasks were divided in: 1) proper visualization of the structure; 2 ) touching the olive with the tip of the needle; 3 ) reposition the needle between the olive and the bottom of the bowl; 4) avoid touching the bottom of the bowl with the needle. The following were considered technical flaws: failure to visualize the structure, incorrect positioning of the needle, and touching the bottom of the bowel with the needle. Failure to perform each task and technical flaws were evaluated by the observer. All residents were evaluated by the same observer, who did not know which group the residents belonged to.

The mean length of time to perform the tasks and the number of technical flaws in each group were evaluated.

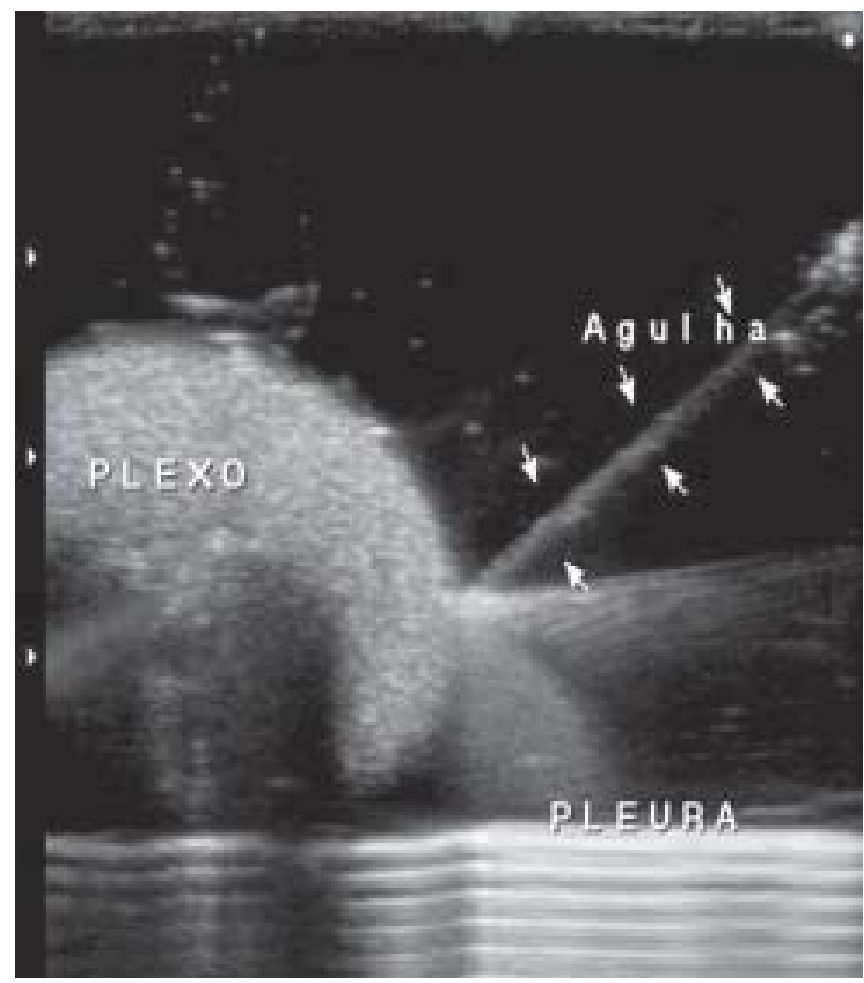

Figure 3 - Ultrasound Image of the Experimental Model. The bottom of the bowl represents the pleura, the olive represents the plexus, and the needle can be visualized.

\section{RESULTS}

The mean length of time to perform the tasks was 37.63 seconds for $\mathrm{G} 1$, which did not presented any technical flaws; 64.4 seconds for G2, with two technical flaws; and 93.83 seconds for G3, with twelve technical flaws (Table I and Chart I).

Time to perform the tasks

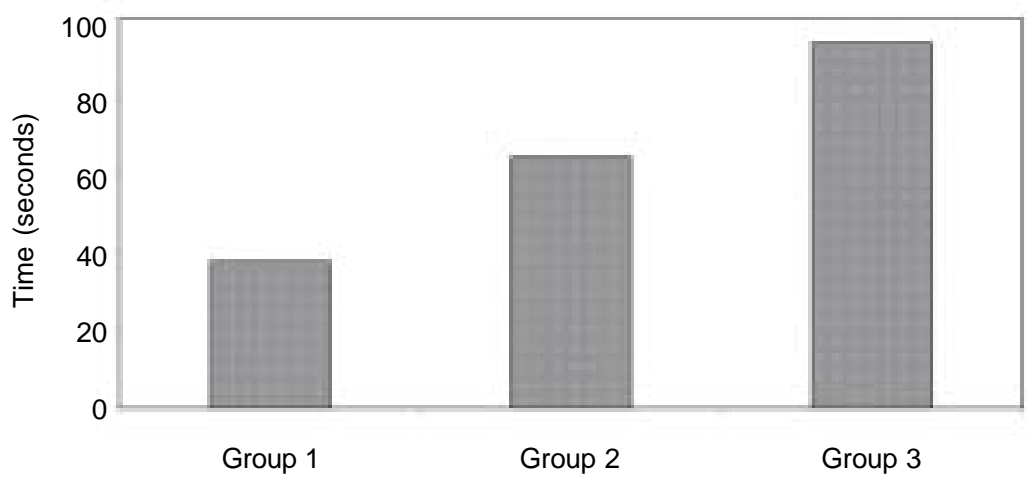

Chart I - Mean Length of Time to Perform the Tasks for Each Group. 
Table I - Distribution of Technical Flaws in the Different Groups

\begin{tabular}{lccc}
\hline & Group 1 & Group 2 & Group 3 \\
\hline $\begin{array}{l}\text { Unable to visualize } \\
\text { the structures }\end{array}$ & 0 & 0 & 0 \\
$\begin{array}{l}\text { Incorrect needle positioning } \\
\begin{array}{l}\text { Touching the bottom } \\
\text { of the bowl }\end{array}\end{array}$ & 0 & 2 & 9 \\
Total technical flaws & 0 & 0 & 2 \\
\hline
\end{tabular}

\section{DISCUSSION}

The use of simulators is common in aeronautical and nuclear industries, in which the operators should be attentive and be trained to deal with situations that might have catastrophic consequences. Proper training allows for fast responses, development of abilities, and improvement of the technique. Anesthesiology is similar to those activities, since it deals with critical situations that demand immediate, effective, and non-iatrogenic responses.

The possible development of a complication during anesthetic blocks justifies the use of the ultrasound, and the proper technique should be developed through simulations and training in experimental models, in teaching and training institutions, under direct supervision of experienced, licensed instructors, before performing nerve blocks in patients.

In the present study, the main finding was the relationship between longer training and better performance of the tasks with reduced incidence of technical flaws, confirming the data reported in the literature, demonstrating that individuals with specific training perform better that those without ${ }^{5}$.

Experimental models currently used to train ultrasoundguided techniques consist of: pig shoulders, breast of turkey, bovine muscle and agar pieces ${ }^{4}$.

The experimental model used has several advantages since it is easily reproducible, available to any anesthesiologist or CET and has a low cost. After the training, residents had more confidence to perform ultrasound-guided blocks in humans. It is important that the anesthesiologist handle and be familiarize with the ultrasound equipment before performing the technique in humans.

The limitation of this study was the small number of participants, and for this reason the results were not subjected to statistical analysis. Besides, it would be ideal to evaluate the performance of the residents before and after the training. More studies are needed to validate the method of simulation used.

This study allowed us to conclude that longer training in an experimental model of ultrasound-guided peripheral nerve block improved the learning curve of the technique simulation.

\section{REFERÊNCIAS - REFERENCES}

01. Marhofer P, Greher M, Kapral S - Ultrasound guidance in regional anaesthesia. Br J Anaesth, 2005;94:7-17.

02. Grau T - Ultrasonography in the current practice of regional anaesthesia. Best Pract Res Clin Anaesthesiol, 2005;19:175-200.

03. Sites BD, Gallagher JD, Cravero J et al. - The learning curve associated with a simulated ultrasound-guided interventional task by inexperienced anesthesia residents. Reg Anesth Pain Med, 2004;29:544-548.

04. Helayel PE, Conceição DB, Oliveira Filho GR - Bloqueios nervosos guiados por ultra-som. Rev Bras Anestesiol, 2007;57:106-123.

05. Cicarelli DD, Coelho RB, Benseñor FEM et al. — Importância do treinamento de residentes em eventos adversos durante anestesia. Experiência com o uso de simulador computadorizado. Rev Bras Anestesiol, 2005;55:151-157.

06. Horlocker TT - Neurologic complications of neuraxial and peripheral blockade. Can J Anesth, 2001;48:R1-R8.

07. Navas AM - Complicaciones de los bloqueos nerviosos periféricos. Rev Esp Anestesiol Reanim, 2006;53:237-248.

08. De Andrés J, Sala- Blanch X - Ultrasound in the practice of brachial plexus anesthesia. Reg Anesth Pain Med, 2002;27:77-89.

09. Sandhu NS, Capan LM - Ultrasound-guided infraclavicular brachial plexus block. Br J Anaesth, 2002;89:254-259.

10. Bodenham AR - Ultrasound imaging by anaesthetists: training and accreditation issues. $\mathrm{Br} \mathrm{J}$ Anaesth, 2006;96:414-417.

\section{RESUMEN}

Baranauskas MB, Margarido CB, Panossian C, Silva ED, Campanella MA, Kimachi PP - Simulacro de Bloqueos Periféricos Guiados por Ultrasonido: Curva de Aprendizaje de los Residentes de Anestesiología del CET-SMA/HSL.

JUSTIFICATIVA Y OBJETIVOS: La técnica de ultrasonido ha sido cada vez más utilizada para la realización de bloqueos de nervios periféricos. Existen pocos relatos en la literatura que analizan la curva de aprendizaje de la técnica de ultrasonido. El objetivo del estudio fue evaluar la curva de aprendizaje de los residentes de Anestesiología del CET-SMA/HSL en bloqueos periféricos guiados por ultrasonido a través de modelo experimental de gelatina.

MÉTODO: Fue desarrollado un modelo experimental con un recipiente lleno de gelatina y aceituna sumergida. Nueve residentes se distribuyeron aleatoriamente en tres grupos (G1, G2, G3) compuestos cada uno, por un R1, un R2 y un R3. Los tres grupos recibieron una explicación teórica. El G1 recibió dos horas de entrenamiento práctico, el G2 una hora y el G3 no fue entrenado. Acto seguido, se les solicitó a los participantes que pusiesen la aguja en el punto medio de la pared de la aceituna, cerca del transductor y reposicionar la aguja entre la aceituna y el fondo del recipiente, simulando la inyección perineural del anestésico. Se evaluaron la velocidad y la eficacia de las tareas, además de las fallas técnicas.

RESULTADOS: El G1 presentó un promedio de tiempo para la realización de las tareas de 37,63 segundos, sin fallas técnicas; en el G2 se observó un promedio de 64,40 segundos, ocurriendo dos fallas técnicas y el G3 presentó un promedio de 93,83 segundos, con doce fallas técnicas.

CONCLUSIONES: El estudio permite concluir que el mayor tiempo de entrenamiento en un modelo experimental de bloqueos periféricos guiados por ultrasonido mejoró la curva de aprendizaje en el simulacro de la técnica. 